\title{
Relations between plasma non-esterified fatty acid metabolism and body fat mobilization in primiparous lactating goats
}

\author{
BY F. R. DUNSHEA* AND A. W. BELL* \\ School of Agriculture, La Trobe University, Bundoora, Victoria 3083, Australia \\ AND T. E. TRIGG $\dagger$ \\ Animal and Irrigated Pastures Research Institute, Kyabram, Victoria 3620, Australia
}

(Received 22 June 1988 - Accepted 26 January 1989)

\begin{abstract}
During early lactation ruminants can mobilize considerable amounts of body fat to maintain milk production. The aim of the present study was to evaluate the efficacy of tritiated water (TOH) and nonesterified fatty acid (NEFA) kinetics as means of monitoring adipose tissue fat mobilization in lactating goats. Body fat, as estimated by a two-pool model of TOH kinetics, and NEFA entry rate were measured in four primiparous goats at days 11,37 and 72 post partum. Estimated body fat decreased by an average of $64 \mathrm{~g} / \mathrm{d}$ between days 11 and 37 of lactation, tending to increase between days 37 and 72 . Plasma NEFA concentrations and NEFA entry rate decreased as lactation advanced, being significantly lower at day 72 than at day 11 of lactation. Both plasma concentrations of NEFA and NEFA entry rate were negatively correlated with calculated energy balance. Plasma NEFA concentrations and NEFA entry rate at days 11 and 37 of lactation were positively related to average body fat losses over the subsequent stage of lactation. These results demonstrate that NEFA kinetics reflect fat mobilization in primiparous lactating goats, particularly during negative energy balance.
\end{abstract}

Fat mobilization: Lactation: Non-esterified fatty acids: Goat.

During early lactation ruminants can mobilize considerable amounts of body tissue, predominantly as fat, to maintain milk production to their genetic potential (Bauman \& Currie, 1980). Feed intake increases gradually during this period but does not become maximal until several weeks after peak milk yield occurs (Bines, 1979).

In order to study the mechanisms involved and factors affecting this mobilization, there is a need for a simple, inexpensive method to measure body composition or estimate energy balance in the live lactating ruminant. One promising technique is the measurement of body water by isotope dilution (Panaretto \& Till, 1963; Foot \& Greenhalgh, 1970; Searle, 1970), particularly when associated with compartmental analysis to separate the major bodywater pools (Byers, 1979). Recently, we have used this approach to predict body composition from live weight and tritiated water (TOH) kinetics in lactating goats (Dunshea et al. 1988 a). Alternatively, the plasma concentrations and kinetics of a number of metabolites have been used as predictors of energy balance. In particular, plasma nonesterified fatty acid (NEFA) concentrations have been related to the productive performance of ruminants in various physiological states (Reid \& Hinks, 1962; Holmes \& Lambourne, 1970; Russel \& Wright, 1983; Bauman et al. 1988; Dunshea et al. 1988 b).

The aim of the present study was to evaluate the relative efficacy of TOH and NEFA kinetics as means of monitoring net fat mobilization and deposition in well-fed goats early in their first lactation.

Present addresses: * Department of Animal Science, Cornell University, Ithaca, NY 14853, USA; † Peptide Technology, PO Box 444, Dee Why, NSW 2099, Australia. 


\section{MATERIALS AND METHODS}

\section{Animals and levels of feeding}

Four primiparous Saanen does aged 23 (SE 0-1) months at parturition and weighing 32-53 $\mathrm{kg}$ at $11 \mathrm{~d}$ post partum were used. Each was surgically prepared with a carotid artery loop (Hecker, 1974) and rumen cannula (Hecker, 1969) before experiments began. All goats received ad lib. a diet of lucerne (Medicago sativa) hay-oaten grain-lupins (Lupinus albus) $(65: 25: 10$, by wt) every $2 \mathrm{~h}$ via a belt-driven automatic feeding system. The diet contained $182 \mathrm{~g}$ crude protein (nitrogen $\times 6.25)$ and $10.0 \mathrm{MJ}$ metabolizable energy $(\mathrm{ME}) / \mathrm{kg}$ dry matter. ME content was based on the apparent digestibility of organic matter (Ministry of Agriculture, Fisheries and Food, 1975) determined in another eight lactating does fed on the same ration (Dunshea, 1987). Dry matter, organic matter and $\mathrm{N}$ digestibilities were $0.664,0.665$ and 0.759 respectively. Kids were removed from the does $2 \mathrm{~d}$ after parturition and the does were machine-milked twice daily at approximately 08.00 and 16.00 hours.

\section{Measurements}

Kinetic measurements were made three times during lactation, at 11 (SE 1.5), 37 (SE 3.5) and 72 (SE $4 \cdot 2) \mathrm{d}$ post partum. At least $24 \mathrm{~h}$ before an infusion polyethylene catheters $(0.80 \mathrm{~mm}$ i.d., $1.20 \mathrm{~mm}$ o.d.; Dural Plastics, Dural, NSW, Australia) were inserted $150 \mathrm{~mm}$ into both an external jugular vein and an exteriorized carotid artery using 16 gauge needles (Medicut; Argyle Medishield, St Louis, MO, USA). Catheters were kept patent by flushing with sterile saline $(9 \mathrm{~g}$ sodium chloride $/ 1)$ containing heparin $(500 \mathrm{kU} / 1)$ and were sealed with stainlesssteel pins. Between samples taken during $\left[1-{ }^{14} \mathrm{C}\right]$-labelled NEFA infusions, the catheters contained sterile saline only.

$N E F A$ kinetics. All NEFA infusates contained an equimolar mixture of $\left[1-{ }^{14} \mathrm{C}\right]$ palmitic, $\left[1-{ }^{14} \mathrm{C}\right]$ stearic and $\left[1-{ }^{14} \mathrm{C}\right]$ oleic acids $(56-57 \mathrm{mCi} / \mathrm{mmol}$, Amersham International plc, Amersham) and were prepared by a modification of the method of Lindsay \& Leat (1977) as described by Dunshea et al. (1988 b). Jugular venous infusions commenced at 10.00 hours and were performed using a syringe pump (Vial Medical, France) at $12.5 \mathrm{ml} / \mathrm{h}(0.25$ $\mu \mathrm{Ci} / \mathrm{min})$ for $3.5 \mathrm{~h}$. Arterial blood sampling $(10 \mathrm{ml})$ for measurement of plasma NEFA concentrations and specific radioactivity (SRA) began after $90 \mathrm{~min}$, with eight blood samples being taken at equally spaced intervals over the next $120 \mathrm{~min}$. Blood samples contained $\mathrm{Na}_{2}$ EDTA $(1 \mathrm{~g} / \mathrm{l})$ as an anticoagulant.

Plasma NEFA were isolated by a modification of the back-extraction method of Pethick et al. (1983). The modification was that $\left[9,10(n)-{ }^{3} \mathrm{H}\right]$ palmitic acid $(1 \mathrm{nCi}, 500 \mathrm{mCi} / \mathrm{mmol}$; Amersham International plc) was added to the plasma to determine recovery of extracted and derivatized NEFA. Isolated NEFA from $1 \mathrm{ml}$ plasma were converted to their methyl esters by refluxing in $2.0 \mathrm{ml}$ sulphuric acid in methanol $(70 \mathrm{~g} / \mathrm{l})$ for $2 \mathrm{~h}$. Heptane $(4 \mathrm{ml})$ and $1.0 \mathrm{ml} \mathrm{NaCl}(40 \mathrm{~g} / 1)$ were added with mixing and the heptane layer containing the fatty acid methyl esters was transferred to a scintillation vial. Heptane was removed by evaporation under a gentle stream of $\mathrm{N}_{2}$ gas and the fatty acid methyl esters were reconstituted in 25 $\mu 1$ heptane. Duplicate $0.5 \mu \mathrm{l}$ samples were injected onto a $2 \mathrm{~m} \times 3 \mathrm{~mm}$ glass column packed with $10 \%$ SP-216-PS on 100-110 mesh Supelcoport (Supelco, Bellefonte, PA, USA) in a Perkin Elmer $F 11$ gas chromatograph at $165^{\circ}$. The molar concentrations of the individual NEFA $(14: 0,16: 0,16: 1,17: 0,18: 0,18: 1,18: 2$ and $20: 0)$ were determined by comparison with the internal standard (150 nmol pentadecanoic acid $(15: 0)$; Sigma, St Louis, MO, USA) and use of appropriate correction factors. The remainder of the sample was dissolved in $5.0 \mathrm{ml}$ scintillation fluid (Anderson \& MacClure, 1973) and counted in a Packard Tri-Carb 460C liquid-scintillation system set in the dual-label mode. Recovery of $\left[9,10(n)-{ }^{3} \mathrm{H}\right]$ palmitic acid was $75-80 \%$ complete. Infusate radioactivity was determined 
after solubilizing $50 \mu \mathrm{l}$ of the infusate in $100 \mu \mathrm{l}$ solubilizing agent (Protosol; New England Nuclear, N. Billerica, MA, USA). NEFA SRA was calculated as disintegrations/min (dpm) per 1 plasma divided by total NEFA concentration ( $\mu \mathrm{mol} / 1$ plasma).

TOH kinetics. Immediately after the $\left[1-{ }^{14} \mathrm{C}\right]$-labelled NEFA infusion the goats were milked, induced to urinate (Corbett et al. 1971) and then weighed. After obtaining a blood sample to determine background or residual TOH SRA, a single dose of TOH $(5 \mathrm{Ci} / 1$; Amersham International plc) diluted in saline $(30 \mathrm{mCi} / \mathrm{l})$ was injected via the jugular catheter $(10 \mu \mathrm{Ci} / \mathrm{kg})$ and followed immediately by $20 \mathrm{ml}$ sterile saline. Jugular blood samples were taken at 15,20,25,30,37,45,55, 80,120,180,300,480,720, 1080 and 1440 min post injection. TOH SRA was obtained by liquid-scintillation counting of duplicate 0.5 $\mathrm{ml}$ samples of plasma water obtained by lyophilization.

Rumen CrEDTA space. Rumen volume was estimated using CrEDTA as a nonradioactive tracer for the solute phase of the rumen digesta (Downes \& McDonald, 1964). Immediately after the TOH injection, $50 \mathrm{ml}$ of a stock solution of CrEDTA $(68 \mathrm{~g} / \mathrm{l})$ was administered via a rumen cannula. Rumen fluid samples $(20 \mathrm{ml})$ were taken via the cannula at $1,2,3,4,6,8,12$ and $24 \mathrm{~h}$ thereafter. These samples were strained through muslin, centrifuged at $5000 \mathrm{~g}$ for $10 \mathrm{~min}$ and the supernatant fraction stored at $-15^{\circ}$ until analysis. Chromium concentration was determined using atomic absorption spectrophotometry at $425.4 \mathrm{~nm}$. Standards were prepared by diluting the CrEDTA stock solution with rumen fluid obtained from an uninfused goat fed on a similar diet.

Calculations and statistics. Whole-body NEFA entry rate was calculated by dividing the infusion rate $(\mathrm{dpm} / \mathrm{h})$ of the mixture of $\left[1-{ }^{14} \mathrm{C}\right]$-labelled NEFA by the SRA of total plasma NEFA after the latter was no longer time-dependent. Plateau SRA was achieved within 1 h.

The TOH SRA $v$. time curve was fitted to a second-order exponential decay function (Shipley \& Clark, 1972; Byers, 1979) using the maximum-likelihood program (MLP; Ross, 1980). TOH pools were calculated by dividing the TOH dose by the zero-time intercepts of the decay function. Body composition was estimated from TOH pools using the equations from Dunshea et al. (1988a) (Table 1).

A single-order exponential equation was used to describe the relation between rumenfluid CrEDTA concentration and time. Linear regressions were applied to the curve relating $\log _{c}$ transformed rumen fluid chromium concentrations and time. Rumen CrEDTA space was calculated by dividing the CrEDTA dose by the concentration at zero time obtained by extrapolation.

Maintenance requirements were assumed to be $0.312 \mathrm{~kJ} \mathrm{ME} / \mathrm{kg}$ live weight ${ }^{0.75}$ per $\mathrm{d}$ (Armstrong \& Blaxter, 1965). Milk energy was estimated using the following prediction equation relating milk energy to milk yield (MY) and day of lactation (D) (Dunshea, 1987):

$$
\begin{gathered}
\text { milk energy }(\mathrm{MJ} / \mathrm{d})=3 \cdot 18+2.81 \mathrm{MY}(\mathrm{kg} / \mathrm{d})-0.78 \ln \mathrm{D}(\mathrm{d}), R^{2} 0.948, \\
\text { residual standard deviation }(\mathrm{RSD}) 0.55 \mathrm{MJ} / \mathrm{d}, n 33 .
\end{gathered}
$$

The partial efficiency of conversion of ME to milk energy $\left(k_{1}\right)$ was assumed to be 0.62 (Agricultural Research Council, 1980). Energy balance was calculated as energy intake less energy for maintenance and milk production.

Statistical and regression analyses were performed using Minitab version 5·1 (Ryan et al. 1985) and Statistical Analysis System (SAS, 1982). Stage of lactation effects were assessed using analysis of variance. Whenever a significant trend was observed contrasts were made using a paired $t$ test. 


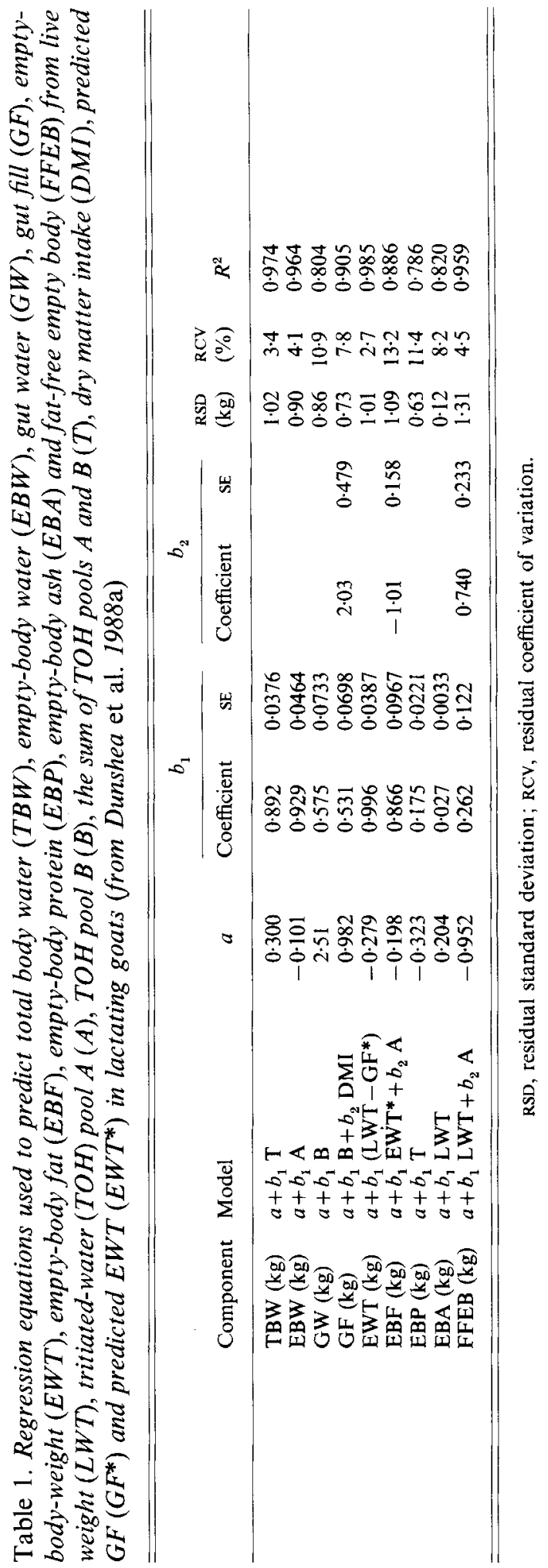


Table 2. Mean milk production, calculated energy balance, dry matter intake, plasma nonesterified fatty acid (NEFA) concentrations and NEFA entry rate in four lactating goats at three stages of lactation

\begin{tabular}{lcccc}
\hline Day of lactation ... & 11 & 37 & 72 & PSE \\
\hline Milk yield $(\mathrm{kg} / \mathrm{d})$ & $2 \cdot 00$ & $2 \cdot 13$ & $1 \cdot 80$ & $0 \cdot 18$ \\
Energy balance $(\mathrm{MJ} \mathrm{ME} / \mathrm{d})$ & $-3 \cdot 20^{\mathrm{a}}$ & $0 \cdot 58^{\mathrm{b}}$ & $1.48^{\mathrm{b}}$ & $0 \cdot 81$ \\
Dry matter intake $(\mathrm{kg} / \mathrm{d})$ & 1.40 & $1 \cdot 63$ & 1.48 & $0 \cdot 13$ \\
Plasma NEFA $(\mu \mathrm{mol} / \mathrm{l})$ & $336^{\mathrm{a}}$ & $196^{\mathrm{ab}}$ & $180^{\mathrm{b}}$ & $25 \cdot 8$ \\
NEFA entry rate $(\mu \mathrm{mol} / \mathrm{h}$ per kg) & $447^{\mathrm{a}}$ & $301^{\mathrm{ab}}$ & $286^{\mathrm{b}}$ & $30 \cdot 6$ \\
\hline
\end{tabular}

a, b Values in the same row with different superscript letters were significantly different $(P<0.05)$

PSE, pooled standard error (df 9); ME, metabolizable energy.

Table 3. Mean body composition estimated from live weight and tritiated water (TOH) pools in four lactating goats at three stages of lactation*

\begin{tabular}{|c|c|c|c|c|}
\hline Day of lactation... & 11 & 37 & 72 & PSE \\
\hline Live wt (kg) & $40 \cdot 5$ & $40 \cdot 4$ & $41 \cdot 1$ & $2 \cdot 70$ \\
\hline Empty-body-wt (kg) & $32 \cdot 3$ & $30 \cdot 8$ & 31.9 & $2 \cdot 24$ \\
\hline Empty-body water $(\mathrm{kg})$ & $21 \cdot 4$ & $21 \cdot 7$ & $21 \cdot 9$ & $1 \cdot 34$ \\
\hline Empty-body fat $(\mathrm{kg})$ & $4 \cdot 32^{\mathrm{a}}$ & $2 \cdot 80^{\mathrm{b}}$ & $3.48^{\mathrm{ab}}$ & 0.583 \\
\hline Empty-body protein $(\mathrm{kg})$ & $5 \cdot 09$ & $5 \cdot 33$ & $5 \cdot 38$ & 0.331 \\
\hline Empty-body ash $(\mathrm{kg})$ & $1 \cdot 28$ & $1 \cdot 28$ & $1 \cdot 28$ & 0.062 \\
\hline Fat-free empty body $(\mathrm{kg})$ & 26.9 & $27 \cdot 0$ & $27 \cdot 4$ & 1.48 \\
\hline Gut fill $(\mathrm{kg})$ & $8 \cdot 24$ & $9 \cdot 55$ & $9 \cdot 18$ & 0.542 \\
\hline TOH pool $A \nmid(k g)$ & $23 \cdot 2$ & 23.5 & $23 \cdot 8$ & 1.43 \\
\hline TOH pool $\mathrm{B}+(\mathrm{kg})$ & $8 \cdot 59$ & $9 \cdot 83$ & $9 \cdot 75$ & 0.547 \\
\hline Rumen CrEDTA pool $+(1)$ & $5 \cdot 23$ & $5 \cdot 98$ & $6 \cdot 33$ & 0.938 \\
\hline
\end{tabular}

a, b Values in the same row with different superscript letters were significantly different $(P<0 \cdot 05)$.

PSE, pooled standard error (df 9).

* Body composition predicted from the equations in Table 1.

$\uparrow$ Determined from TOH kinetics.

$\ddagger$ Determined by rumen dilution of CrEDTA.

\section{RESULTS}

\section{Production}

Milk production peaked at 2.09 (SE 0.36) $\mathrm{kg} / \mathrm{d}$ after 4 weeks of lactation, averaging 1.91 (SE $0 \cdot 10) \mathrm{kg} / \mathrm{d}$ over the first 10 weeks of lactation. Milk yields at the three stages of lactation when metabolic measurements were made are shown in Table 2.

Dry matter intake (DMI) tended to increase over the first 5 weeks of lactation and then plateaued. Calculated energy balance increased over the duration of the experiment, being significantly lower at day 11 than at days 37 or 72 of lactation $(P<0.05)$. Average energy balances over the periods $11-37 \mathrm{~d}$ and $37-72 \mathrm{~d}$ were estimated to be -2.50 (SE 0.70$)$ and +1.14 (SE 0.53) MJ ME/d respectively.

\section{Body composition}

Body compositions at the three stages of lactation are given in Table 3. Body fat was significantly lower at day 37 than at day 11 of lactation $(P<0.05)$. Average net loss of body 


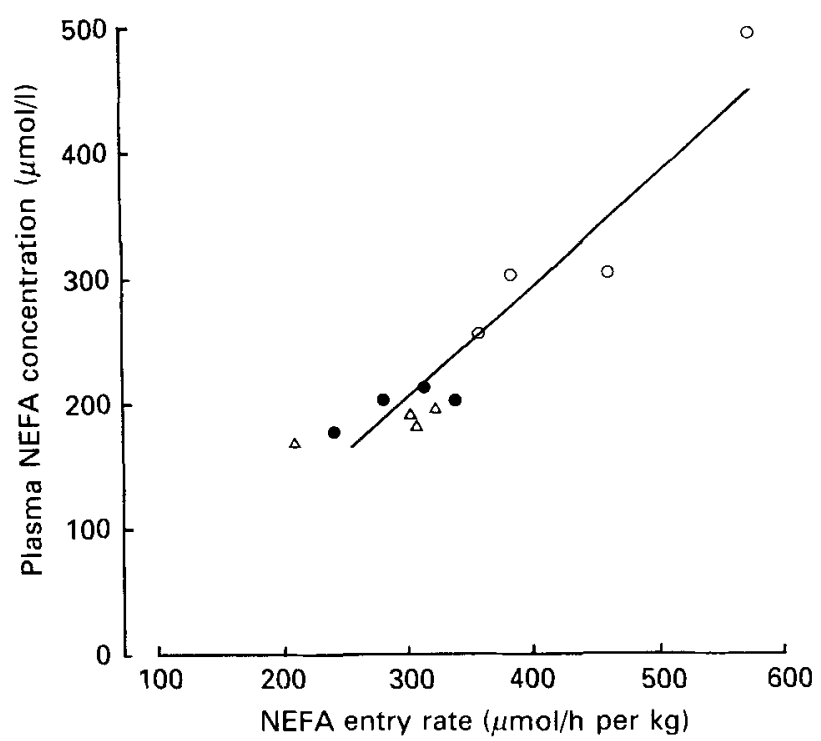

Fig. 1. Relation between plasma non-esterified fatty acid (NEFA) concentrations and NEFA entry rate in lactating goats at $11(\mathrm{O}), 37(\odot)$ and $72(\triangle) \mathrm{d}$ post partum.

$$
Y=-60 \cdot 1+0 \cdot 874 X, R 0 \cdot 935
$$

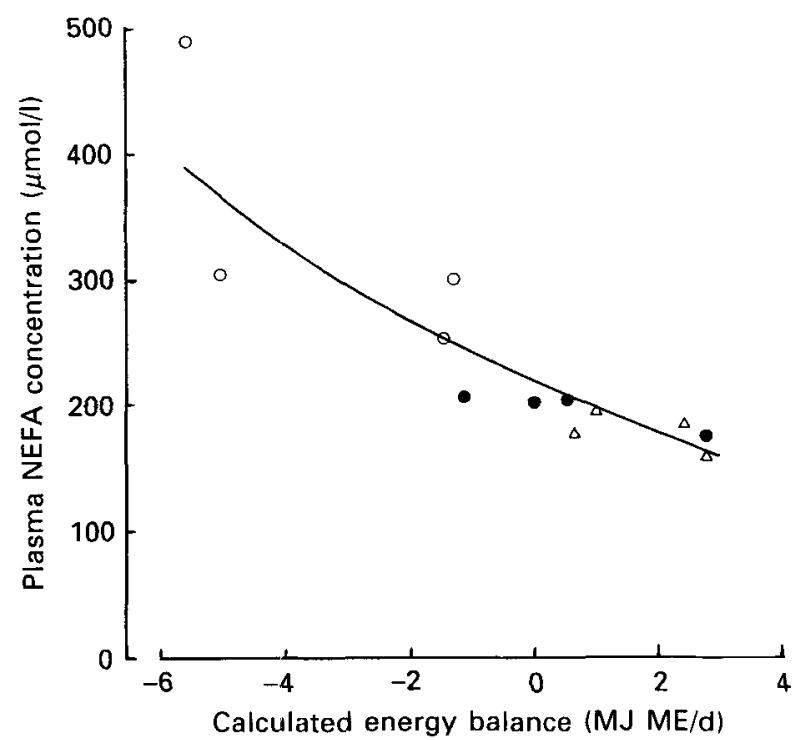

Fig. 2. Relation between plasma non-esterified fatty acid (NEFA) concentrations and calculated energy balance in lactating goats at $11(\mathrm{O}), 37(\mathrm{O})$ and $72(\triangle) \mathrm{d}$ post partum.

$$
Y=217 e^{-0.104 x}, R-0.905
$$

fat over this period was 64 (SE 17) g/d. Body fat tended to increase between days 37 and 72 of lactation, with three of the four goats showing net fat deposition.

There were no significant differences in any other estimated body components at the three stages of lactation, although gut fill tended to be higher at day 37 than at day 11 post partum $(P=0.12)$. 


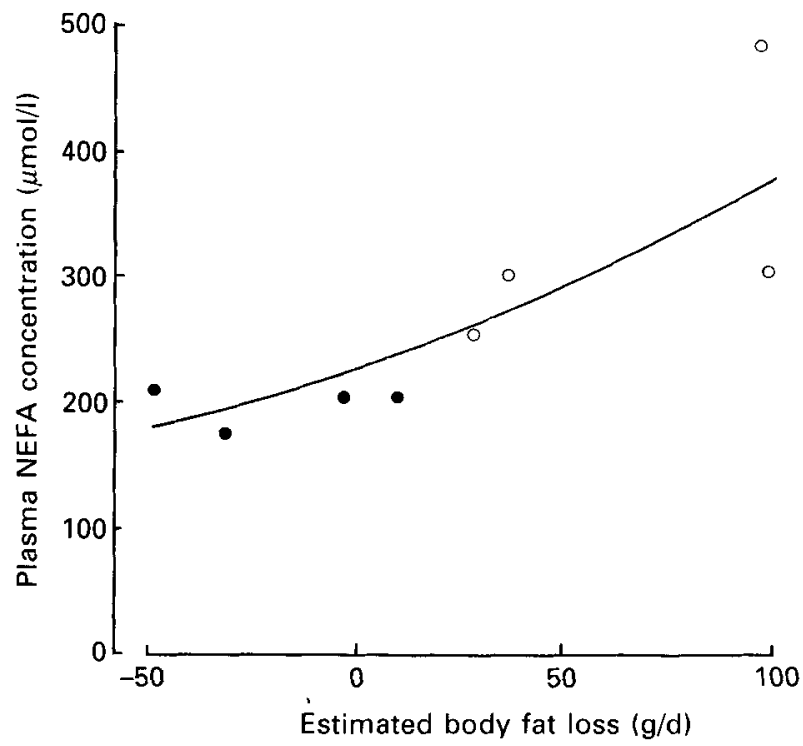

Fig. 3. Relation between plasma non-esterified fatty acid (NEFA) concentrations in lactating goats at $11(\mathrm{O})$ and 37 (O) d post partum and estimated body fat loss over the subsequent stage of lactation.

$$
Y=224 e^{0.00525 x}, R 0.851
$$

\section{NEFA metabolism}

Plasma NEFA concentrations and NEFA entry rate decreased as lactation advanced with the differences between days 11 and 72 being significant $(P<0.05)$. Plasma concentrations of NEFA were highly and positively correlated with whole-body NEFA entry rate (Fig. 1; $R^{2} 0.882, P<0.001$ ) and inversely related to calculated energy balance (Fig. $2 ; R^{2} 0.819$, $P<0.001)$. NEFA entry rate was also negatively correlated with calculated energy balance $\left(R^{2} 0.706, P<0.001\right)$.

Plasma NEFA concentrations at days 11 and 37 of lactation were related to average estimated daily body fat loss over the subsequent interval between metabolic measurements (Fig. $\left.3 ; R^{2} 0.725, P<0.01\right)$. A similar relation existed for NEFA entry rate $\left(R^{2} 0.561\right.$, $P<0.05$ ).

There were no significant differences in the molar percentages of any individual plasma NEFA at any stage of lactation. When the values for the three stages of lactation were pooled, palmitic, stearic and oleic acids accounted for 19.3 (SE 0.5), 40.0 (SE 0.9) and 24.9 (SE $0.8) \mathrm{mol} \%$ of plasma NEFA respectively.

\section{DISCUSSION}

Mobilization of body fat during early lactation has been reported in well-fed multiparous ewes (Cowan et al. 1981) and high-producing dairy cows (Flatt et al. 1965; Moe et al. 1971; Chilliard et al. 1984; Martin \& Ehle, 1986), but little is known about the ability of immature ruminants to call on body reserves. Under normal management conditions dairy animals are well fed towards the end of gestation to replenish body energy stores in preparation for the ensuing lactation. However, first-lactation ruminants have rarely reached mature body size at parturition, and during late pregnancy feed intake may be insufficient to maintain maternal body growth and allow deposition of adequate energy stores for use during early 
lactation. Nevertheless, mobilization of body fat occurred despite the goats being far from mature size. Their average live weight and estimated body fat content at day 11 of lactation were 40.5 (SE 4.6) and 4.32 (SE 0.88) kg respectively. At the same stage in their subsequent lactation 1 year later the live weight and estimated body fat content of the same four goats were 53.4 (SE 5.1) and 12.7 (SE 2.6) kg respectively (Dunshea, 1987). Present results are consistent with observations that 2-year-old ewes with moderate fat reserves at lambing (18-24\% of live weight as fat) mobilized 1.5 and $3.0 \mathrm{~kg}$ of fat during the first 5 weeks of lactation when fed to produce 1.5 and 0.75 litres milk/d respectively (Foot et al. 1984).

Comparisons were made between average energy balances and changes in body fat over the two periods of lactation studied, assuming published values for the partial efficiencies of use of ME and tissue energy (Agricultural Research Council, 1980). Thus, between days 11 and 37 of lactation fat mobilization averaged $64 \mathrm{~g} / \mathrm{d}$, or the equivalent of $3.4 \mathrm{MJ} \mathrm{ME} / \mathrm{d}$, whereas average energy balance over this period was $-2.5 \mathrm{MJ} \mathrm{ME} / \mathrm{d}$. Over the period 37-72 d average lipid accretion was $19 \mathrm{~g} / \mathrm{d}$, or approximately $1.4 \mathrm{MJ} \mathrm{ME} / \mathrm{d}$, while average energy balance was $1 \cdot 1 \mathrm{MJ} \mathrm{ME} / \mathrm{d}$. Given that maintenance requirements and partial efficiencies of energy use are not fixed and vary with level of production and energy status, these estimated values for energy balance and fat energy loss are quantitatively similar, demonstrating that $\mathrm{TOH}$ kinetics can provide realistic estimates of changes in body composition during early lactation.

Using indirect calorimetry, Flatt et al. (1965) demonstrated that it was possible for a dairy cow to lose an average of $2 \mathrm{~kg}$ fat $/ \mathrm{d}$ during early lactation with no concomitant change in live weight. It is also apparent from the present study that relying on live-weight changes alone provides little information on changes in body composition in lactating goats. This is primarily due to changes in body fat being masked by changes in gut fill (GF), as in these goats there was a tendency for GF to increase between days 11 and 37 of lactation. Cowan et al. (1980) observed that GF, as predicted by DMI, increased rapidly during early lactation in sheep, making it difficult to develop universally applicable prediction equations relating body composition to live weight and $\mathrm{D}_{2} \mathrm{O}$ space. In this context, the two-pool model of TOH kinetics can account for changes in GF and gut water (Dunshea et al. $1988 a$ ).

The high correlations between plasma NEFA levels and entry rates provide confidence in using plasma NEFA levels as an index of NEFA metabolism in lactating goats. Bauman et al. (1988) also found a significant correlation between NEFA entry rate, estimated using $\left[1-{ }^{14} \mathrm{C}\right]$ palmitic acid as a tracer, and plasma NEFA concentrations in lactating cows $\left(R^{2} 0.67\right)$. The approach adopted here was to infuse a mixture of $\left[1-{ }^{14} \mathrm{C}\right]$ palmitic, $\left[1-{ }^{14} \mathrm{C}\right]$ stearic and $\left[1-{ }^{14} \mathrm{C}\right]$ oleic acids to minimize any heterogeneity in the behaviour of individual NEFA, as has been suggested by some workers (Annison et al. 1967; Lindsay, 1978). This technique was proposed by Bell \& Thompson (1979) who infused a mixture of $\left[1-{ }^{14} \mathrm{C}\right]$-labelled NEFA, in the proportions commonly observed in bovine plasma, as a tracer for NEFA in steers. They found a highly significant correlation between plasma NEFA concentrations and NEFA entry rates $\left(R^{2} 069\right)$. We have also related plasma NEFA concentrations to NEFA entry rate determined in this manner in non-lactating, non-pregnant goats and found a similar correlation (Dunshea et al. 1988 b).

The inverse correlation between energy balance and both plasma NEFA concentrations and NEFA entry rate is evidence of increased fat mobilization during lactation-induced undernutrition. Similar relations have been found in continuously fed, multiparous, lactating goats (Dunshea \& Bell, 1987) and dairy cows (Bauman et al. 1988). Konig et al. (1979) found that palmitic acid entry rate decreased between weeks 2 and 9 of lactation in dairy cows. Body-weight had stabilized and milk yield had peaked by weeks $5-6$, so the cows were most likely approaching, or in, a positive energy balance by week 9 of lactation. 
The regression equation relating plasma NEFA concentrations with energy balance in the present study predicts a value of $217 \mu \mathrm{mol} / 1$ at zero energy balance. Chilliard et al. (1987) also found that plasma NEFA concentrations were inversely related to energy balance in lactating goats $\left(R^{2} 0.504, P<0.001\right)$. Although the regression equation was not given, visual appraisal of their line diagram suggests an NEFA concentration of approximately $200 \mu \mathrm{mol} / \mathrm{l}$ at zero energy balance.

Parker \& Lewis (1978) observed that plasma NEFA concentrations immediately after the morning milking were significantly correlated with energy balance in fifteen lactating cows. The correlation was higher in cows fed on a restricted ration than in those fed at a higher level. The tendency for plasma NEFA concentrations and NEFA entry rate to approach a plateau at energy balances above zero in the present study is consistent with this. Not surprisingly then, Bartle et al. (1983) were unable to find a significant relation between plasma NEFA levels and energy status in beef cattle which were in positive energy balance during the period 7-12 weeks post partum.

As the animals in the present study were fed ad lib., it may be fortuitous that significant correlations were found between indices of NEFA metabolism and daily fat loss over the subsequent periods of lactation. Konig et al. (1979) observed that NEFA entry rate, determined using $\left[9,10(n)-{ }^{3} \mathrm{H}\right]$ palmitic acid as a tracer, was highest during times of substantial live-weight loss in dairy cows, but was quantitatively greater than these liveweight losses. A number of reasons could be given for this, including the failure to account for basal triglyceride fatty acid turnover, overestimation of NEFA entry rate when using labelled palmitic acid as a tracer, and that live-weight loss is not always a good measure of fat mobilization in lactating ruminants. Trigg \& Topps (1981) found prefeeding plasma NEFA levels to be directly related to fat loss, determined by $\mathrm{D}_{2} \mathrm{O}$ dilution, in four undernourished lactating beef cattle $\left(R^{2} 0.76, P<0 \cdot 1\right)$. Chilliard et al. (1984) observed a high correlation between average prefeeding plasma NEFA levels and changes in estimated body fat in lactating dairy cows $\left(R^{2} 0.90, P<0.01\right)$. The relation was more useful in cows fed on a restricted ration who were mobilizing more body fat than well-fed cows. Nevertheless, it appears that the goats which had the highest plasma NEFA levels and NEFA entry rates at day 11 of lactation lost the greatest amount of body fat over the next $26 \mathrm{~d}$. Also, it is apparent from Fig. 3 that as goats moved into positive energy balance, increased fat deposition was not associated with significantly reduced NEFA entry rate, once again confirming that NEFA kinetics are poor indices for quantifying energy surplus.

The present findings demonstrate that fat mobilization can occur in primiparous goats fed ad lib. during early lactation, allowing them to perform closer to their production potential. The techniques used in the present study have complementary strengths and weaknesses. For example, techniques which measure body composition at specific points in time provide no knowledge of the current energy status of the animal. In contrast, plasma NEFA concentrations and NEFA kinetics provide a more immediate assessment of energy status, but are of limited value for quantifying energy surplus.

The authors wish to thank Mr K. D. Chandler, Miss R. Fitzpatrick and Miss R. Vavala for technical assistance and care of the animals. F. R. D. was supported by a grant from the Australian Dairy Research Committee.

\section{REFERENCES}

Agricultural Research Council (1980). The Nutrient Requirements of Ruminant Livestock. Slough: Commonwealth Agriculture Bureaux.

Anderson, L. E. \& MacClure, W. O. (1973). An improved scintillation cocktail of high solubilizing power. Analytical Biochemistry 51, 173-179. 
Annison, E. F., Brown, R. E., Leng, R. A., Lindsay, D. B. \& West, C. E. (1967). Rates of entry and oxidation of acetate, glucose, $\mathrm{D}(-)$ - $\beta$-hydroxybutyrate, palmitate, oleate and stearate, and rates of production and oxidation of propionate and butyrate in fed and starved sheep. Biochemical Journal 104, 135-147.

Armstrong, D. G. \& Blaxter, K. L. (1965). Effects of acetic and propionic acids on energy retention and milk secretion in goats. In Energy Metabolism, pp. 59-72 [K. L. Blaxter, editor]. London: Academic Press.

Bartle, S. J., Preston, R. L. \& Males, J. R. (1983). Evaluation of plasma free fatty acids as indicators of energy status in lactating beef cows. Nutrition Reports International 28, 345-354.

Bauman, D. E. \& Currie, W. B. (1980). Partitioning of nutrients during pregnancy and lactation: a review of mechanisms involving homeostasis and homeorhesis. Journal of Dairy Science 63, 1514-1529.

Bauman, D. E., Peel, C. J., Steinhour, W. D., Reynolds, P. J., Tyrrell, H. F., Brown, A. C. G. \& Haaland, G. L. (1988). Effect of bovine somatotropin on metabolism of lactating dairy cows: influence on rates of irreversible loss and oxidation of glucose and nonesterified fatty acids. Journal of Nutrition 118, 1031-1047.

Bell, A. W. \& Thompson, G. E. (1979). Free fatty acid oxidation in bovine muscle in vivo: effects of cold exposure and feeding. American Journal of Physiology 237, E309-E315.

Bines, J. A. (1979). Voluntary feed intake. In Feeding Strategies for the High Yielding Dairy Cow, pp. 23-28 [W. H. Broster and H. Swan, editors]. London: Granada Press.

Byers, F. M. (1979). Measurement of protein and fat accretion in growing beef cattle through isotope dilution procedures. In Ohio Beef Cattle Research Progress Report, Series 79-1, pp. 36-47. Wooster, Ohio: Ohio Agricultural Research Development Center

Chilliard, Y., Robelin, J. \& Remond, B. (1984). In vivo estimation of body lipid mobilization and reconstitution in dairy cattle. Canadian Journal of Animal Science 64, Suppl., 236-237.

Chilliard, Y., Sauvant, D., Morand-Fehr, P. \& Delouis, C. (1987). Relations entre le bilan énergétique et l'activité métabolique du tissu de la chèvre au cours de la première moitié de la lactation. Reproduction, Nutrition, Développement 27, 307--308.

Corbett, J. L., Farrell, D. J., Leng, R. A., McClymont, G. L. \& Young, B. A. (1971). Determination of the energy expenditure of penned and grazing sheep from estimates of carbon dioxide entry rate. British Journal of Nutrition 26, 277-291.

Cowan, R. T., Robinson, J. J., McHattie, I. \& Fraser, C. (1980). The prediction of body composition in live ewes in early lactation from live weight and estimates of gut contents and total body water. Journal of Agricultural Science, Cambridge 95, 515-522.

Cowan, R. T., Robinson, J. J., McHattie, I. \& Pennie, K. (1981). Effects of protein concentration in the diet on milk yield, change in body composition and the efficiency of utilization of body tissues for milk production in ewes. Animal Production 33, 111-120.

Downes, A. M. \& McDonald, I. W. (1964). The chromium-51 complex of ethylene-diamine-tetra-acetic acid as a soluble rumen marker. British Journal of Nutrition 18, 153-162.

Dunshea, F. R. (1987). Use of labile tissue reserves during chronic undernutrition or early lactation in dairy goats. PhD Thesis, La Trobe University, Bundoora, Australia.

Dunshea, F. R. \& Bell, A. W. (1987). Non-esterified fatty acid (NEFA) reesterification and fat mobilization in goats during early lactation. Journal of Dairy Science 70, Suppl., P10.

Dunshea, F. R., Bell, A. W., Chandler, K. D. \& Trigg, T. E. (1988 a). A two-pool model of tritiated water kinetics to predict body composition in unfasted lactating goats. Animal Production 47, 435-445.

Dunshea, F. R., Bell, A. W. \& Trigg, T. E. (1988 b). Relations between plasma non-esterified fatty acid metabolism and body tissue mobilization during chronic undernutrition in goats. British Journal of Nutrition 60, 633-644.

Flatt, W. P., Moore, L. P., Hooven, N. W. \& Plowman, R. D. (1965). Energy metabolism studies with a highproducing dairy cow. Journal of Dairy Science 48, 797 Abstr.

Foot, J. Z. \& Greenhalgh, J. F. D. (1970). The use of deuterium oxide space to determine the amount of body fat in pregnant Blackface ewes. British Journal of Nutrition 24, 815-825.

Foot, J. Z., Heazlewood, P. G. \& Joseph, K. (1984). Partitioning of energy in young lactating sheep. In Reproduction in Sheep, pp. 269-27! [D. R. Lindsay and D. T. Pearce, editors]. Canberra: Australian Academy of Science.

Hecker, J. F. (1969). A simple rapid method for inserting rumen cannulae in sheep. Australian Veterinary Journal 45, 293294.

Hecker, J. F. (1974). Experimental Surgery on Small Ruminants. London: Butterworths.

Holmes, J. H. G. \& Lambourne, L. J. (1970). The relation between plasma free fatty acid concentration and the digestible energy intake of cattle. Research in Veterinary Science 11, 27-36.

Konig, B. A., Parker, D. S. \& Oldham, J. D. (1979). Acetate and palmitate kinetics in lactating dairy cows. Annales de Recherches Vétérinaires 10, 368-370.

Lindsay, D. B. (1978). The effect of feeding pattern and sampling procedure on blood parameters. In The Use of Blood Metabolites in Animal Production, pp. 99-120 [D. Lister, editor]. Thames Ditton: British Society of Animal Production.

Lindsay, D. B. \& Leat, W. N. F. (1977). Oxidation and metabolism of linoleic acid in fed and fasted sheep. Journal of Agricultural Science, Cambridge 89, 215-221. 
Martin, R. A. \& Ehle, F. R. (1986). Body composition of lactating and dry Holstein cows estimated by deuterium dilution. Journal of Dairy Science 69, 88-98.

Ministry of Agriculture, Fisheries and Food (1975). Energy Allowances and Feeding Systems for Ruminants. Technical Bulletin no. 33. London: H.M. Stationery Office.

Moe, P. W., Tyrrell, H. F. \& Flatt, W. P. (1971). Energetics of body tissue mobilization. Journal of Dairy Science 54, 548-553.

Panaretto, B. A. \& Till, A. R. (1963). Body composition in vivo. II. The composition of mature goats and its relationship to the antipyrine, tritiated water, and $\mathrm{N}$-acetyl-4-aminoantipyrine spaces. Australian Journal of Agricultural Research 14, 926-943.

Parker, B. N. J. \& Lewis, G. (1978). In The Use of Blood Metabolites in Animal Production, pp. 121-132 [D. Lister, editor]. Thames Ditton: British Society of Animal Production.

Pethick, D. W., Lindsay, D. B., Barker, P. J. \& Northrop, A. J. (1983). The metabolism of circulating nonesterified fatty acids by the whole animal, hind-limb muscle and uterus of pregnant ewes. British Journal of Nutrition 49, 129-143.

Reid, R. L. \& Hinks, N. T. (1962). Studies on the carbohydrate metabolism of sheep. XVIII. The metabolism of glucose, free fatty acids, and ketones after feeding and during fasting or undernourishment of non-pregnant, pregnant and lactating ewes. Australian Journal of Agricultural Research 13, 1124-1136.

Ross, G. J. S. (1980). MLP: Maximum Likelihood Program (Version 3.06), Rothamsted, Herts.: Rothamsted Experimental Station.

Russel, A. J. F. \& Wright, I. A. (1983). The use of blood metabolites in the determination of energy status in beef cows. Animal Production 37, 335-343.

Ryan, T. A. Jr, Joiner, B. L. \& Ryan, B. F. (1985). Minitab: Version 5.1 Massachusetts: Duxbury Press.

SAS (1982). SAS User's Guide: Statistics. Cary, NC: SAS Institute, Inc.

Searle, T. W. (1970). Body composition in lambs and young sheep and its prediction in vivo from tritiated water space and body weight. Journal of Agricultural Science, Cambridge 74, 357-362.

Shipley, R. A. \& Clark, R. E. (1972). Tracer Methods for in vivo Kinetics. New York: Academic Press.

Trigg, T. E. \& Topps, J. H. (1981). Composition of body-weight change during lactation in Hereford $\times$ British Friesian cows. Journal of Agricultural Science, Cambridge 97, 147-157. 